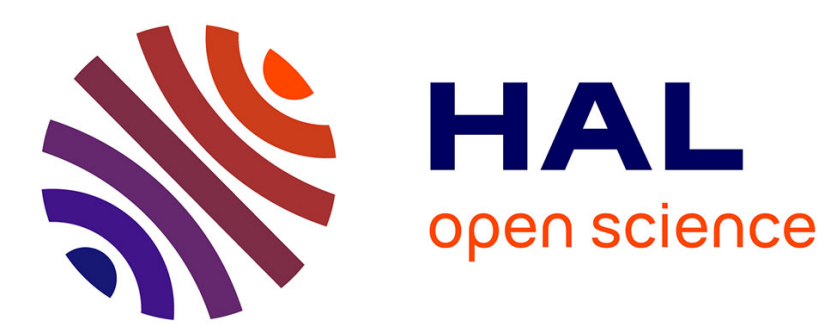

\title{
Commute Green! The Potential of Enterprise Social Networks for Ecological Mobility Concepts
}

Christian Zinke, Julia Friedrich

\section{To cite this version:}

Christian Zinke, Julia Friedrich. Commute Green! The Potential of Enterprise Social Networks for Ecological Mobility Concepts. 20th Working Conference on Virtual Enterprises (PRO-VE), Sep 2019, Turin, Italy. pp.128-139, 10.1007/978-3-030-28464-0_12 . hal-02478771

HAL Id: hal-02478771

https://hal.inria.fr/hal-02478771

Submitted on 14 Feb 2020

HAL is a multi-disciplinary open access archive for the deposit and dissemination of scientific research documents, whether they are published or not. The documents may come from teaching and research institutions in France or abroad, or from public or private research centers.
L'archive ouverte pluridisciplinaire HAL, est destinée au dépôt et à la diffusion de documents scientifiques de niveau recherche, publiés ou non, émanant des établissements d'enseignement et de recherche français ou étrangers, des laboratoires publics ou privés.

\section{(c)(1)}

Distributed under a Creative Commons Attribution| 4.0 International License 


\title{
Commute Green! The Potential of Enterprise Social Networks for Ecological Mobility Concepts
}

\author{
Christian Zinke-Wehlmann and Julia Friedrich \\ Institute for Applied Informatics (InfAI), Gordelerring 9, \\ 04109 Leipzig, Germany \\ \{zinke,friedrich\}@infai.org
}

\begin{abstract}
The paper discusses the potential of collaborative networks $(\mathrm{CN})$ to support eco-friendly commuting and create ecological benefits. It therefore develops framework conditions within the concept of social business. The objective is to show up solutions to reduce air pollution, frustration, stress caused by rush hour traffic related to the inflexible working hours. Therefore, relevant social business framework conditions to support eco-friendly behavior have been identified. As a result, the paper shows how social business can combine digitally driven empowerment of workers and corporate responsibility for human and environment. It points out the potential for ecological as well as for social benefits.
\end{abstract}

Keywords: Social Business, Enterprise Social Network, Ecological mobility concepts; Sustainable Commute, Gamification

\section{Introduction}

The success of social network technology and digital collaboration leads to a transformation of work [1-3]. This transformation concerns internal communication and collaboration processes [4, 5] like knowledge exchange [6] as well as external marketing activities [7] and business innovation processes [8, 9]. Moreover, the popularity of social media and social software that allow every participant to be heard and every voice to matter lead to a transformation of workers' self-conception $[10,11]$. Concurrently to this, in the times of raising awareness for climate change $[12,13]$ people start or intensify the reconsideration of their own lifestyle ${ }^{1}$ which is particularly apparent in the popularity of the Fridays for future (FFF) movement $[14,15]$. Increasing pollution and politically driven debates like the regulation or restriction of diesel vehicles in European countries [16] bring the idea of a (personal) ecological footprint $[17,18]$ into focus.

In the sense of corporate responsibility for human and environment, a modern employer is expected to take these idealistic values of his employees into account. Moreover, the so-called "war for talents" [19] puts high pressure on companies to create attractive work environments and to respond to the needs of their employees in the spirit of the new work concept [20]. The combination of a digitally driven empowerment of

\footnotetext{
${ }^{1}$ Green consumption [16,17], veganism [18,19] or sustainable living [20] represent the growing environmental awareness and can be understood as a modern lifestyle forms.
} 
workers and the sense for ecological issues gives rise to new demands on companies. Moreover, in accordance to the new work concept [20], these individual and internal attitudes towards sustainability and environmental awareness need to be consistent.

The idea of the research project SB:digital, where this work is conducted, is to meet these modern work requirements by creating an added value for workers and companies through the concept of social business [21]. Within the context of the project, social business is understood as a strategy and framework whose application is linked to the generation of a social, ecological and economic benefit as a primary goal from the use of social or collaborative networks $(\mathrm{CNs})$, e.g. enterprise social networks, virtual organizations or virtual enterprises [1]. Thereof, the main research question of our work is: How can Social Business create framework conditions for a sustainable support of ecological commute behavior?

\section{Methodology}

In order to address the research question on how social business can support environmental-friendly commute behavior, we have chosen a design-oriented approach [22]. The presented results need to be understood as conceptual work and have not yet been tested due to the not yet completed implementation phase. According to Peffers [22], who developed a generative procedure for computer science, there are six essential steps in design science: (I) problem explanation, (II) development of solution approach, (III) artifact design and implementation, (IV) demonstration, (V) evaluation (and initiation of another design cycle, if necessary) and (VI) result communication. While we have already described the problem (I), the objective of this work is to conceptualize (II) and design (III) a solution approach in order to analyze the potential of CN and to identify relevant social business framework conditions to support eco-friendly behavior. These framework conditions are inspired by the Human-TechnologyOrganization analyze framework [23, 24] and the analysis of socio-technical systems [25]. The main idea is to analyze the influencing and conductive factors and conditions for eco-friendly behavior within organizations/CNs from three main perspectives: the organizational, the human and the technological. The exemplarily presented "everyday case" is based on an empirical business case from the project SB:Digital. Thus, here it represents an adapted case-study, in the way Yin understand it: "The allencompassing feature of a case study is its intense focus on a single phenomenon within its real-life context...[Case studies are] research situations where the number of variables of interest far outstrips the number of data points" [25]. The following chapter will introduce the case.

The case: Commuting - an everyday life scenario: In Germany, more than $50 \%$ of all employees have strict working time conditions (rigid working hours, less influence on pause times and limited selectable vacation within determined time slots) and only $9 \%$ of dependent workers have agreements regarding home office with their employer [26]. In other words, this means that the majority of employees must be at work at fixed times. The resulting commute overload causes rush hours on the streets, especially in business districts. "A commuter is defined as every employee whose workplace is outside its local community" [27]. In 2016 for almost $70 \%$ of employees, the daily 
commute distance between home and work was at least $5 \mathrm{~km}$, of which $20 \%$ had to

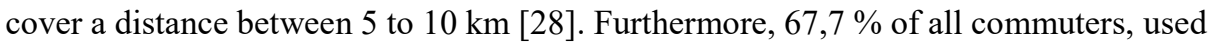
a car for commuting [28]. The standard vehicle occupancy in Germany during commute is 1,2 persons per car [29]. Furthermore, even new cars have an average $\mathrm{CO} 2$ emission of $118.5 \mathrm{~g} / \mathrm{km}$ [30] - no congestion factored. This shows, that car sharing or an occasional change from motorized private transport to active commute (bike, walking) or public transport would have a significant impact on emissions [31, 32]. By understanding commuting as a social phenomenon, which affects everyone and that requires for a joint solution, every passive commuter (car, public transport) could reduce its own environmental footprint significantly.

\section{Background and Related Work}

\subsection{Collaborative Networks and Enterprise Social Networks}

Enterprise Social Networks (ESN) are well known web-based platforms for digital communication and exchange of digital artifacts [33]. Via individual profiles, employees can present themselves and their work but also connect and communicate with other employees [34]. Examples are platforms like wikis, microblogs and social networking platforms [35]. CNs are cross-organizational network, where social interaction via ESN is time- and location-independent [36]. This allows employees to stay connected across national borders and time zones. Companies often implement ESN with the goal of increasing productivity or innovation [33]. However, although the potential of ESN as a platform for internal as well as inter-company knowledge exchange between actors has been recognized [37], there is no research on the possible use of ESN to promote environmentally friendly behavior. Thus, this paper does not address the major topics of ecological product or process innovation but puts the focus on framework conditions to support individual eco-friendly behavior change in the context of cross-organizational collaboration.

\subsection{Motivation for Behavioral Change}

The main objective of a business commute project as we describe it, is to motivate employees for a change of behavior. A growing number of communities all over the world is already trying to establish sustainable mobility concepts [38, 39]. Even though the primary motives of the stakeholders may differ, the commute project needs to take all perspective into consideration to assure a long-lasting success by addressing intrinsic motives. A purely incentive based extrinsic motivation causes only a short change of behavior but not a sustainable change of attitude [40]. The motive of the company, for example, might be a mitigation of the parking space shortage or the whish for stress reduction to prevent sick leaves. The employees, on the other hand, might also wish to avoid stressful commuting with traffic and long-lasting searches for parking spaces [41] or strive for a more sustainable living and environmental awareness. In a first step, all the different objectives towards commute as well as barriers and factors for individual resistance should be identified. 
Change of behavior patterns towards pro-environmental behavior requires for pressure or strong individual motivation. But as Ölander and Thøgersen [42] note, the free choice of the individuum is the decisive point to ensure "consistency between attitudes and behaviour" and, thus, a sustainable change of behavior. Motivation can be addressed by incentives. Incentives address individual motives and can thus be enhancer but cannot create motivation which is not at least subliminally present which means that they cannot be able to cause behavioral change if they are not compatible with the individual value system [43, 44]. Moreover, incentives need to be desirable for the addressee [45]. Both motivation and ability are key determinants for human behavior. While a lot of psychological works "studying behavior as a function of processes internal to the individual" [46], we agree with the idea that behavior change need the integration of external and internal functions as independent variables - e.g. resources and social embedment (e.g. in terms of relatedness). The most powerful advantage of CNs is the community aspect. Online communities strengthen feelings of relatedness [47]. In the context of badge systems, Kwon et al. [48] describe the effect of social incentives that work through comparison and social benchmarking. But online communities are not only useful in the context of incentive creation but can furthermore be used to promote a value system and create awareness for community relevant aspects such as ecology. Thus, social comparison and the growing awareness for ecological sustainability can both be exploited in order to establish a shared value system within CNs.

\section{Social Business Framework Conditions for Eco-friendly Behavior}

Within this chapter, we are going to identify and initiate the design of artefacts within the developed framework conditions on the presented case. These artefacts need to be elaborated in on-going work. A general overview which shows the relations between the three different analysis layers of human, $\mathrm{CN}$ and technology and interdependencies in terms of behavior change can be found in Fig. 1 .

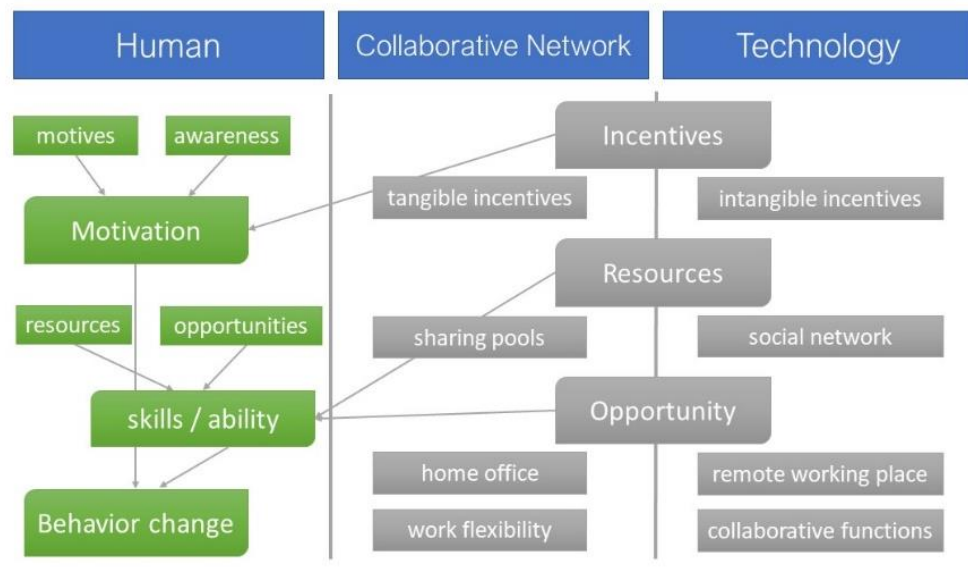

Fig. 1. Social business framework conditions 


\subsection{The Human Factor}

To initiate a change of behavior, humans need to be motivated, which works both positively by addressing motives and the individual value system ${ }^{2}$ as well as negatively by addressing environmental concerns and clarifying the negative consequences of a non-changing of e.g. commute behavior [50]. Furthermore, they require for the ability in terms of resources and opportunities to behave different. Intrinsic motivation is one of the key factors for a sustainable change of behavior and an ultimately as a result of personal experience and internalization change of attitude [40], but the problem is that there is no single way to motivate, every individual have to be motivated in different ways. Communities and companies can, therefore, act as "motivators" and create both awareness and incentives to support motivational growth and to initiate behavioral change. Next to the individual motivation, employees need the ability to change. This means, that they require for adequate resources (Do I have the capabilities?) as well as for the opportunity (Is it doable for me?) to change their commute routine. As it has been shown in fig. Fig. 1, all three components, namely motivation, resources and opportunity, are key factors for the human behavior. Within this work, we do not go into deep psychological discourses like, e.g., Ohtomo and Hirose [51] did. Instead, we focus on the overall framework conditions (human, organization, technology) and its relations. More precisely, we ask, which framework conditions are supporting the motivation, the resources and the opportunities of employee to behave in an ecofriendlier way?

\subsection{The Collaborative Network}

To have the greatest possible impact, we believe that collaborative networks in forms of regional limited ESN, established for industry parks and conurbation, supports business independent, cross-organizational cooperation. In addition, a regional reference enables a stronger identification with the commute project as well as a social embedding in a shared value system. All organizations as well as the local administration do need to develop a framework specifically and individually for the target conurbation (based on infrastructure (traffic, schools, public transport etc.), types of enterprises and employee, landscape etc.). Even local administrations can have the role of mediator for the eco-driven collaboration network and give general advices and help lines like [52] suggest for SME. Enterprises do have the possibilities to share cost, attract working place and motivate employee. Within the network, important resources can be set. Likewise, tangible incentives can be created in order to strengthen awareness and collective rethinking of commute behavior and using network effects. A collection of examples is given in Fig. 2.

Beside the resources and opportunities, collaborative networks also can set different incentives. Based on the different point systems, individual points can be transferred into vouchers, convertible, e.g., for bicycle equipment or free public transport rides. On a group level, points can be transformed into team events or included, e.g., into donation campaigns for regional ecological project. As it has been shown be Ettema et al. [53],

\footnotetext{
${ }^{2}$ EU study show: "the more the individuals think that they are playing an important role in protecting the environment, the higher the probability of behaving ecologically" [49].
} 
monetary incentives with no further contextualization towards mode switching have no lasting effect on behavior once they are withdrawn.

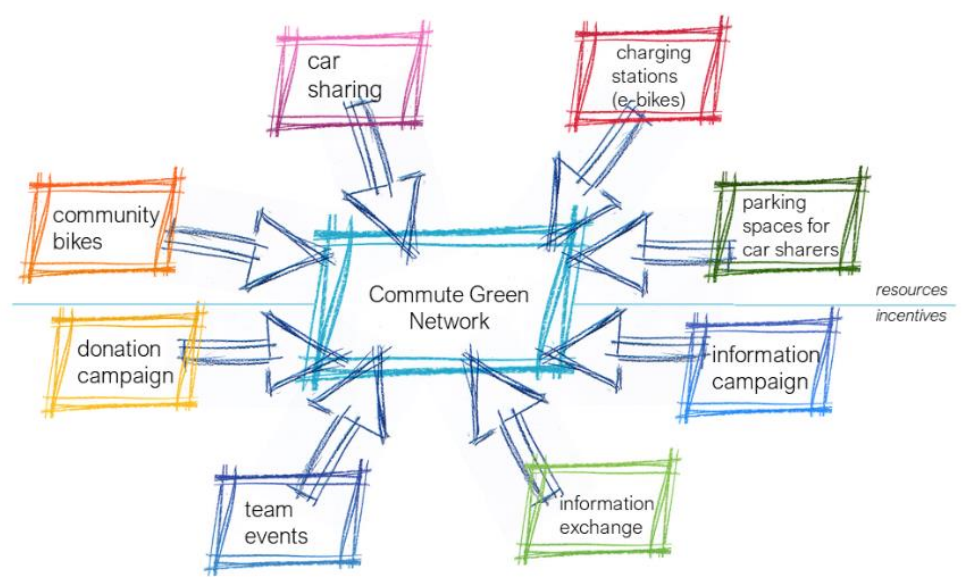

Fig. 2. Network design approaches to support ecological commute behavior

Table 1. Incentive potential for pro-ecological behavior change

\begin{tabular}{|c|c|c|c|}
\hline & Motivation & $\begin{array}{l}\text { Eco-friendly } \\
\text { embedment }\end{array}$ & Social embedment \\
\hline Voucher & $\begin{array}{l}(+) \text { tangible incentive } \\
\text { like e-bike voucher } \\
\text { have ecological impact } \\
\text { and support attitude } \\
\text { change through } \\
\text { experience }\end{array}$ & $\begin{array}{l}\text { (+) corresponding to } \\
\text { the intended action } \\
\text { (bike repairing), } \\
\text { regional- and } \\
\text { ecological adaptable }\end{array}$ & $\begin{array}{l}(+/-) \text { vouchers for } \\
\text { group activities foster } \\
\text { joint objectives, but } \\
\text { may cause rivalry } \\
\text { between individuals / } \\
\text { teams }\end{array}$ \\
\hline $\begin{array}{l}\text { Financial } \\
\text { incentives }\end{array}$ & $\begin{array}{l}(+/-) \text { strong extrinsic } \\
\text { incentive for short-term } \\
\text { behavioral adjustment }\end{array}$ & $\begin{array}{l}\text { (-) no relevance for } \\
\text { eco-friendly attitude }\end{array}$ & $\begin{array}{l}\text { (-) high chance of } \\
\text { rivalry }\end{array}$ \\
\hline $\begin{array}{l}\text { Free } \\
\text { working } \\
\text { time }\end{array}$ & $\begin{array}{l}(+/-) \text { highly motivating, } \\
\text { less connection to eco- } \\
\text { friendly attitude }\end{array}$ & $\begin{array}{l}\text { (-) no relevance for } \\
\text { eco-friendly attitude }\end{array}$ & $\begin{array}{l}\text { (-) high chance of } \\
\text { rivalry }\end{array}$ \\
\hline $\begin{array}{l}\text { Funding } \\
\text { campaigns }\end{array}$ & $\begin{array}{l}(+) \text { addresses intrinsic } \\
\text { motivation / altruism }\end{array}$ & $\begin{array}{l}(+) \text { regional- and } \\
\text { ecological adaptable }\end{array}$ & $\begin{array}{l}(+) \text { joint design of the } \\
\text { (working) environment } \\
\text { foster teamwork }\end{array}$ \\
\hline Equipment & $\begin{array}{l}(+/-) \text { extrinsic incentive } \\
\text { for short-term } \\
\text { behavioral adjustment }\end{array}$ & $\begin{array}{l}(+) \text { regional- and } \\
\text { ecological adaptable }\end{array}$ & $\begin{array}{l}(+/-) \text { foster teamwork, } \\
\text { may strengthen silo- } \\
\text { mentality (team vs. } \\
\text { team) }\end{array}$ \\
\hline Team events & $\begin{array}{l}(+/-) \text { foster affiliation, } \\
\text { potential negative } \\
\text { impact on voicing } \\
\text { concerns }\end{array}$ & $\begin{array}{l}(+) \text { regional- and } \\
\text { ecological adaptable }\end{array}$ & $\begin{array}{l}(+) \text { foster teamwork to } \\
\text { achieve joint objective }\end{array}$ \\
\hline
\end{tabular}


From our point of view, it is important not only to set any tangible incentives, but also to adapt these incentives for the context (to foster eco-friendly behavior and acting). Moreover, the social embedment is one of the key concepts to foster motivation. Thus, it seems useful to analyze potential incentives regarding their motivation opportunity, their adaptability (and embedment) to eco-friendly concepts and their social embedment as it is done in Table 1 .

\subsection{Technology to Set Incentives in CNs Promoting Ecological Behavior}

The technological basis for a collaborative network built the digital social network (e.g. Humhub) that allows for a barrier free digital communication between multiple stakeholders (e.g. companies in an industrial estate). It is an important resource ${ }^{3}$ for all actors. The network as itself supports a seamless and open information exchange between all stakeholders. This way, users are supported in building car sharing communities to enhance the car occupancy or share their favorite (bike) routes or running tracks.

Within the application, it is furthermore possible to provide useful information to employees which may have an impact on their mobility behavior. Such information might be the daily weather prognosis, current fine dust load of the region or traffic jams on the commute route.

Based on this technical system, it is possible to use gamification in order to create incentives for users. Due to its positive impact on motivation [54] and behavior change, we chose a gamification approach for the incentive design process. In general, in the consideration of incentives, a distinction between internal and external incentives is made [55]. While internal incentive are an integral part of an activity [56] and trigger emotions like fun or ambition, external incentives like bonus payments or reputation are tied to preconditions [57] and can thus be understood as tangible compensation that require for a certain effort. The following Table 2 shows exemplary incentives that are the result of the artifact design.

Table 2. Incentives to promote ecological commute behavior

\begin{tabular}{|c|c|c|}
\hline $\begin{array}{l}\text { Gamification } \\
\text { element }\end{array}$ & $\begin{array}{l}\text { Addressed } \\
\text { motivation }\end{array}$ & Implementation \\
\hline Points & Ambition & $\begin{array}{l}\text { (1) specific mobility behavior according to the } \\
\text { environmental footprint } \\
\text { (2) saved fuel costs with car sharing }\end{array}$ \\
\hline $\begin{array}{l}\text { Meaningful } \\
\text { story (virtual } \\
\text { parc) }\end{array}$ & Relatedness & $\begin{array}{l}\text { (3) individual growing trees (including employees/alias } \\
\text { name plate) } \\
\text { (4) leaves can be "earned" by passing challenges/ } \\
\text { redeeming of points }\end{array}$ \\
\hline
\end{tabular}

\footnotetext{
${ }^{3}$ The term resource is ambiguous. Here it refers also to the capabilities.
} 


\begin{tabular}{|c|c|c|c|}
\hline $\begin{array}{l}\text { Time } \\
\text { comparison }\end{array}$ & $\begin{array}{l}\text { self- } \\
\text { efficiency, } \\
\text { comparison, } \\
\text { fun }\end{array}$ & $\begin{array}{l}\text { (6) } \\
\text { (7) }\end{array}$ & $\begin{array}{l}\text { visualization of commute distance/route \& time } \\
\text { (individual time tracking from the apartment door to } \\
\text { the workplace) } \\
\text { showing differences for different variants (bicycle vs. } \\
\text { car, etc.) } \\
\text { Visualization of times spent in traffic jams and } \\
\text { avoided congestion times when using bicycles/public } \\
\text { transport }\end{array}$ \\
\hline $\begin{array}{l}\text { Feedback } \\
\text { (eco statistics) }\end{array}$ & $\begin{array}{l}\text { relatedness, } \\
\text { progression, } \\
\text { altruism }\end{array}$ & $\begin{array}{l}\text { (8) } \\
\text { (9) }\end{array}$ & $\begin{array}{l}\text { visualization of personal/group } \mathrm{CO}^{2} \text { commute } \\
\text { footprint } \\
\text { (real-time) ecological company footprint }\end{array}$ \\
\hline $\begin{array}{l}\text { Feedback } \\
\text { (health } \\
\text { statistics) }\end{array}$ & $\begin{array}{l}\text { ambition, } \\
\text { fun }\end{array}$ & $\begin{array}{l}(\mathbf{1 0}) \\
(\mathbf{1 1}) \\
(\mathbf{1 2})\end{array}$ & $\begin{array}{l}\text { burned bike calories / walked steps } \\
\text { conversion of calories into favorite food to choose } \\
\text { (you burned x calories, that corresponds to } 2 \text { pieces of } \\
\text { cake/ } 1 \text { burger in the cafeteria/...) } \\
\text { active commute time }\end{array}$ \\
\hline Simulation & $\begin{array}{l}\text { ambition, } \\
\text { altruism }\end{array}$ & (13) & $\begin{array}{l}\text { effects of (partial) changeover from car to car sharing/ } \\
\text { cycling/public transport on pollution/ } \mathrm{CO}^{2} \text { footprint }\end{array}$ \\
\hline $\begin{array}{l}\text { Challenge \& } \\
\text { rewards }\end{array}$ & $\begin{array}{l}\text { ambition, } \\
\text { fun }\end{array}$ & (15) & $\begin{array}{l}\text { badges for achievement of target } \\
\text { time/calories/emission } \\
\text { achievement of target, based on individual and group } \\
\text { points }\end{array}$ \\
\hline
\end{tabular}

What have to be taken into account in the design and implementation of incentives is, that they need to be adjusted to the corporate culture [54]. Moreover, in order to support the consciousness building for pro-environmental behavior, the design of incentives should be adapted to the context (e.g., leaves for the virtual tree instead of simple points). Furthermore, it has to be kept in mind, that incentives do not unfold their potential automatically, but need to be designed to meet the needs of their recipients [58]. Additionally, it is important to consider, that incentives that put a hugh pressure on its recipients by primarily focusing on competition and rivalry, such as rankings and associated tangible rewards, bear the risk of cheating [59] and a displacement of positive motives (pro-ecological behavior) by negative motivation (egoism, status) [60].

Enabling social collaboration through digital resources and intangible incentives, created through gamification, is a promising approach to foster eco-friendly commute behavior. Moreover, the work conditions of the employee do also affect it. In order to achieve more flexibility in commuting, employers must be open to change, particularly with regard to time constraints. On technical side, that includes a remote working place with collaborative functions to enable social collaboration (e.g. to have the flexibility to negotiate travel times). 


\section{Discussion and Future Directions}

We have discussed social business framework conditions to enable eco-friendly behavior within collaborative networks. Therefore, we developed and discussed different conditions of the human, technology and organizations dimensions. Our main requirement or condition is to set up a digital environment, where employees get the possibility to interact and collaborate. Within the project SB:Digital, we discuss the different technical and organizational conditions in various environments and first deployments of technical features (point system, alternate vehicle suggestion) have been started. In further steps we plan to implement the presented approach (in parts) and evaluate the mode of action, benefits and risks as well as the barriers and contexts. While some validation aspects can be part of the technical solution (e.g. bike and share usages), other aspects, like stress level, will be harder discoverable. Therefor specific methods have to be developed.

Acknowledgments. The German Federal Ministry of Education and Research have funded the work leading to this publication under grant number 02L15A070 (Project: SB:Digital). The authors thank for the funding.

\section{References}

1. Camarinha-Matos, L.M., Afsarmanesh, H.: Collaborative Networks. In: Wang, K., Kovacs, G.L., Wozny, M., Fang, M. (eds.) Knowledge Enterprise: Intelligent Strategies in Product Design, Manufacturing, and Management, 207, pp. 26-40. Springer US (2006)

2. Patroni, J., Briel, F. von, Recker, J.: How Enterprise Social Media Can Facilitate Innovation. IT Prof. 18, 34-41 (2016)

3. Westerman, G., Bonnet, D., McAfee, A.: Leading digital. Turning technology into business transformation. Harvard Business Review Press, Boston, Mass. (2014)

4. Reychav, I., Ndicu, M., Wu, D.: Leveraging social networks in the adoption of mobile technologies for collaboration. Computers in Human Behavior 58, 443-453 (2016)

5. Cook, N.: Enterprise 2.0. Routledge (2017)

6. Majchrzak, A., Faraj, S., Kane, G.C., Azad, B.: The Contradictory Influence of Social Media Affordances on Online Communal Knowledge Sharing. J Comput-Mediat Comm $19,38-55$ (2013)

7. Alalwan, A.A., Rana, N.P., Dwivedi, Y.K., Algharabat, R.: Social media in marketing: A review and analysis of the existing literature. Telematics and Informatics 34, 1177-1190 (2017)

8. Lehmkuhl, T., Baumol, U., Jung, R.: Towards a Maturity Model for the Adoption of Social Media as a Means of Organizational Innovation. In: 2013 46th Hawaii International Conference on System Sciences, pp. 3067-3076. IEEE (2013 - 2013)

9. Kuegler, M., Smolnik, S., Kane, G.: What's in IT for employees? Understanding the relationship between use and performance in enterprise social software. The Journal of Strategic Information Systems 24, 90-112 (2015)

10. Weinberg, B.D., Ruyter, K. de, Dellarocas, C., Buck, M., Keeling, D.I.: Destination Social Business: Exploring an Organization's Journey with Social Media, Collaborative Community and Expressive Individuality. Journal of Interactive Marketing 27, 299-310 (2013) 
11. Schneckenberg, D.: Web 2.0 and the empowerment of the knowledge worker. J of Knowledge Management 13, 509-520 (2009)

12. Biesbroek, G.R., Swart, R.J., Carter, T.R., Cowan, C., Henrichs, T., Mela, H., Morecroft, M.D., Rey, D.: Europe adapts to climate change: Comparing National Adaptation Strategies. Global Environmental Change 20, 440-450 (2010)

13. Sarkodie, S.A., Strezov, V.: Economic, social and governance adaptation readiness for mitigation of climate change vulnerability: Evidence from 192 countries. The Science of the total environment 656, 150-164 (2019)

14. Fridays for Future, https://fridaysforfuture.org/

15. Taylor M, Neslen A, Brooks L.: Youth climate strikes to take place in more than 100 countries, http://www.theguardian.com/education/2019/mar/14/youth-climate-strikes-totake-place-in-almost-100-countries-greta-thunberg

16. Diesel Information Hub: Where in Europe can I drive my diesel car?, https://dieselinformation.aecc.eu/where-in-europe-can-i-drive-my-diesel-car/

17. Global Footprint Network, https://www.footprintnetwork.org/

18. Wackernagel, M., Rees, W.E.: Our ecological footprint. Reducing human impact on the earth. New Society Publ, Gabriola Island, BC (1998)

19. Beechler, S., Woodward, I.C.: The global "war for talent". Journal of International Management 15, 273-285 (2009)

20. Hackl, B., Wagner, M., Attmer, L., Baumann, D.: New Work: Auf dem Weg zur neuen Arbeitswelt. Springer Fachmedien Wiesbaden, Wiesbaden (2017)

21. Digitale Soziale Netzwerke als Mittel zur Gestaltung attraktiver Arbeit, https://sbdigitial.infai.org

22. Peffers, K., Tuunanen, T., Gengler, C., Rossi, M., Hui, W., Virtanen, V., Bragge, J.: The design science research process: A model for producing and presenting information systems research. Proceedings of First International Conference on Design Science Research in Information Systems and Technology DESRIST, 83-106 (2006)

23. Strohm, O., Escher, O.P. (eds.): Unternehmen arbeitspsychologisch bewerten. Ein MehrEbenen-Ansatz unter besonderer Berücksichtigung von Mensch, Technik und Organisation. vdf Hochschulverl. an der ETH Zürich, Zürich (1997)

24. Ulich, E.: Arbeitssysteme als Soziotechnische Systeme - eine Erinnerung. Psychology of Everyday Activity, Vol. 6 / No. 1, ISSN 1998-9970. Psychologie des Alltagshandeln / Psychology of Everyday Activity 6, 4-12 (2013)

25. Yin, R.K.: Case study research. Design and methods. Sage, Los Angeles (2009)

26. Wöhrmann, A.M., Gerstenberg, S., Hünefeld, L., Pund, F., Reeske-Behrens, A., Brenscheidt, F., Beermann, B.: Arbeitszeitreport Deutschland 2016. Verlag Kettler GmbH, Bönen (2016)

27. Peine, K., Helferich, A.: MyQommute - An App as Sustainable Mobility Concept. In: Conference proceedings ICE/IEEE ITMC. 2018 IEEE International Conference on Engineering, Technology and Innovation (ICE/ITMC) : Stuttgart, 17.06.-20.06.2018, pp 1-9. IEEE, Piscataway, NJ (2018)

28. Statistisches Bundesamt: Erwerbstätige nach Stellung im Beruf, Entfernung, Zeitaufwand und benutztem Verkehrsmittel für den Hinweg zur Arbeitsstätte 2016 in \%, https://www.destatis.de/DE/Themen/Arbeit/Arbeitsmarkt/Erwerbstaetigkeit/Tabellen/pend ler1.html

29. Mobilität in Deutschland 2008. Bonn, Berlin (2010)

30. No improvements on average $\mathrm{CO} 2$ emissions from new cars in 2017

31. Bearman, N., Singleton, A.D.: Modelling the potential impact on $\mathrm{CO} 2$ emissions of an increased uptake of active travel for the home to school commute using individual level data. Journal of Transport \& Health 1, 295-304 (2014) 
32. Farrell, S., McNamara, D., Caulfield, B.: Estimating the Potential Success of Sustainable Transport Measures for a Small Town. Transportation Research Record: Journal of the Transportation Research Board, 97-102 (2010)

33. McAfee, A.: Enterprise 2.0: the dawn of emergent collaboration. IEEE Eng. Manag. Rev. $34,38(2006)$

34. Subramaniam, N., Nandhakumar, J., Baptista John, J.: Exploring social network interactions in enterprise systems: the role of virtual co-presence. Info Systems J 23, 475499 (2013)

35. Behrendt, S., Richter, A., Trier, M.: Mixed methods analysis of enterprise social networks. Computer Networks 75, 560-577 (2014)

36. Qureshi, S.: Adaptation in Distributed Projects: Collaborative Processes in Digital Natives and Digital Immigrants. In: Proceedings of the 39th Annual Hawaii International Conference on System Sciences (HICSS'06), 202c-202c. IEEE (2006 - 2006)

37. Mack, D., Vilberger, D.: Leitfäden: Wie geht man systematisch vor für den Social-MediaEinsatz? (Social-Media-Navigator). In: Mack, D., Vilberger, D. (eds.) Social Media für KMU, 47, pp. 63-99. Springer Fachmedien Wiesbaden, Wiesbaden (2016)

38. SHARE-North: Shares Mobility Solutions for a Liveable and Low-Carbon North Sea Region, https://share-north.eu/partners/

39. Gudmundsson, H.: Making concepts matter: sustainable mobility and indicator systems in transport policy. International Social Science Journal 55, 199-217 (2003)

40. Finke, I., Will, M.: Motivation for Knowledge Management. In: Mertins, K., Heisig, P., Vorbeck, J. (eds.) Knowledge Management, pp. 66-91. Springer Berlin Heidelberg, Berlin, Heidelberg (2003)

41. Gatersleben, B., Uzzell, D.: Affective Appraisals of the Daily Commute. Environment and Behavior 39, 416-431 (2007)

42. ölander, F., ThØgersen, J.: Understanding of consumer behaviour as a prerequisite for environmental protection. J Consum Policy 18, 345-385 (1995)

43. Gneezy, U., Meier, S., Rey-Biel, P.: When and Why Incentives (Don't) Work to Modify Behavior. Journal of Economic Perspectives 25, 191-210 (2011)

44. Kohn, A.: Why Incentive Plans Cannot Work. Harvard Business Review, 54-63 (1993)

45. Brandenberg, A.: Anreizsysteme zur Unternehmenssteuerung. Deutscher Universitätsverlag, Wiesbaden (2001)

46. Guagnano, G.A., Stern, P.C., Dietz, T.: Influences on Attitude-Behavior Relationships. Environment and Behavior 27, 699-718 (1995)

47. Moisander, J.: Group Identity, Personal Ethics and Sustainable Development Suggesting New Directions For Social Marketing Research. In: Jochem, E., Sathaye, J., Bouille, D. (eds.) Society, Behaviour, and Climate Change Mitigation, 8, pp. 127-156. Kluwer Academic Publishers, Dordrecht (2003)

48. Kwon, K.H., Halavais, A., Havener, S.: Tweeting badges: user motivations for displaying achievement in publicly networked environments. Cyberpsychology, behavior and social networking 18, 93-100 (2015)

49. Lajunen, T., Parker, D., Summala, H.: Does traffic congestion increase driver aggression? Transportation Research Part F: Traffic Psychology and Behaviour 2, 225-236 (1999)

50. Kollmuss, A., Agyeman, J.: Mind the Gap: Why do people act environmentally and what are the barriers to pro-environmental behavior? Environmental Education Research 8, 239-260 (2002)

51. Ohtomo, S., Hirose, Y.: The dual-process of reactive and intentional decision-making involved in eco-friendly behavior. Journal of Environmental Psychology 27, 117-125 (2007)

52. Klewitz, J., Hansen, E.G.: Sustainability-oriented innovation of SMEs: a systematic review. Journal of Cleaner Production 65, 57-75 (2014) 
53. Ettema, D., Knockaert, J., Verhoef, E.: Using incentives as traffic management tool: empirical results of the "peak avoidance" experiment. Transportation Letters 2, 39-51 (2010)

54. Hamari, J., Koivisto, J., Sarsa, H.: Does Gamification Work? A Literature Review of Empirical Studies on gamification. In: 47th Hawaii International Conference on System Sciences (HICSS), pp. 3025-3034 (2014)

55. Friedrich, J., Becker, M., Kramer, F., Wirth, M., Schneider, M.: Incentive design and gamification for knowledge management. Journal of Business Research (2019)

56. Zaunmüller, H.: Anreizsysteme für das Wissensmanagement in KMU. Deutscher Universitätsverlag, Wiesbaden (2005)

57. Fishbach, A., Choi, J.: When thinking about goals undermines goal pursuit. Organizational Behavior and Human Decision Processes 118, 99-107 (2012)

58. Suh, A., Wagner, C.: How gamification of an enterprise collaboration system increases knowledge contribution. An affordance approach. J of Knowledge Management 21, 416431 (2017)

59. Pascual-Ezama, D., Dunfield, D., Gil-Gomez de Liano, B., Prelec, D.: Peer effects in unethical behavior. Standing or reputation? PloS one 10, e0122305 (2015)

60. Hanus, M.D., Fox, J.: Assessing the effects of gamification in the classroom. A longitudinal study on intrinsic motivation, social comparison, satisfaction, effort, and academic performance. Computers \& Education 80, 152-161 (2015) 